\title{
EFFECT OF THE CHANGE OF CLIMATE INDICATORS ON AGRICULTURAL YIELDS IN SON LA PROVINCE
}

\author{
Nguyen The Hung ${ }^{1, *}$, Nguyen Huu Quyen ${ }^{2, *}$ \\ ${ }^{1}$ Climate change department - Hanoi University of Natural Resources and Environment, \\ No 41 A, PhuDien Road, North-Tu Liem district, Ha Noi Viet Nam \\ ${ }^{2}$ Vietnam Institute of Meteorology, Hydrology and Environment, \\ No.62, Nguyen Chi Thanh Road, Dong Da District, Ha Noi, Viet Nam \\ *Email: hung.dhqg@gmail.com; nhquyen13@gmail.com
}

Received: 13 October 2016; Accepted for publication: 30 September 2017

\begin{abstract}
Due to climate change, the agro-climatic indicators in Son La province has changed in the following trends: (i) the total heat in the Winter - Spring crop and the Summer crop as well as the total annual heat have increased; (ii) The amount of time in a year with temperature below 20 degrees has shortened; the amount of time in a year with temperatures above 25 degrees has lengthened; (iii) the absolute minimum temperature tends to increase rapidly; (iv) the rainfall in Winter - Spring crop has increased slightly whereas the season rainfall and total annual rainfall tend to decrease. The climatic factors in Son La province obviously affect rice yield in the Winter - Spring crop, the Summer crop as well as corn and soybeans. However, compared with other crops, soybean yield is less related to climatic factors. There are major differences in climate characteristics between the high and the low crops yield year. However, these differences depend on the type of the crop and the harvest season.
\end{abstract}

Keywords: climate change, climate indicator, crop yields, Son La.

\section{INTRODUCTION}

Along with agricultural land loss due to sea level rise, climate change also greatly affects the farming sector through many impacts (rising temperatures, precipitation change and the occurrence of extreme weather phenomenon, etc.) $[1,2,3]$. this change not only directly influences the crops (seasonality, yield and quality of agricultural products, etc.), but also has indirect effects through other species (pollinators, harmful organisms, etc.). Therefore, assessing changing trends of agro-climatic indicators and their impacts on crop yields in context of climate change has profound practical significance to adapt to climate change.

Son La province is located in the north-western part of Vietnam, which has a strategic role in the development of socio-economy and politics with topological diversity.possessing much potential. Son La province is assessed to have many advantages for developing cultivation [4] however, in recent years, under the impacts of climate change, Son La has always faced natural disasters and extreme weather (frost, cold weather, drought, etc.), which badly influences many aspects, especially food security. 
Besides assessing the changing trend of agro-climatic indicators in context of climate change, this paper also aims to evaluate the effect of this change on the productivity of some main crops in Son La province to produce supporting basis for decision makers enhancing their natural resources management policies as well as socio-economic planning.

\section{MATERIALS AND METHODS}

\subsection{Collecting information}

Meteorological data: Average air temperature, minimum air temperature, evaporation, precipitation data collected from Son La meteorological station (from 1961 to 2013) are used for analysis and evaluation.

Information concerning harvest season, crop yields is collected from the Bureau of Statistics and the related boards in Son La province (from 1996 to 2013) and from reports related to agricultural production such as harvest season composition, cultivated area, productivity and yields [5].

\subsection{Assessing changing trends of agro-climatic indicators}

Recently, the changing trend of historical climatic and agro-climatic indicators is often evaluated based on the calculation of the slope of the linear regression line $[2,3,6]$, the equation as following:

$$
X=a_{0}+a_{1} t
$$

where $X$ is calculated from the data series $x_{1}, x_{2}, \ldots, x_{n}$, where $x_{i}$ represents the observed data at time $\mathrm{i}$; $\mathrm{t}$ is the time step, could be months, years, decades ..., $\mathrm{a}_{0}$ is the cut-off coefficient, $\mathrm{a}_{1}$ : is the slope (if $\mathrm{a}_{1}>0 \rightarrow$ the series tends to increase, if $\mathrm{a}_{1}<0 \rightarrow$ the series tends to decrease ).

Studying the changing trend of agro-climatic indicators in Son La province is based on a number of key criteria (total average air temperature; the starting and ending day with temperatures over 20 degrees, 25 degrees; the absolute minimum temperature and total rainfall).

\subsection{Assessing effects of climate on crop yields}

At the present, there are two approaches to assess the effects of climate on crop yields, with different methods [2,3]: (1) Time series analysis for plan method quantitatively simulates the process of photosynthesis, respiration, growth, and heat and moisture regimes within the plant population. This is a complex problem which is compounded by a series of physiological processes influenced by environmental factors and cultivation regimes. Therefore, this method requires conducting field experiments to determine the input parameters for the model (2). Statistical method examines the relationship between crop yield and climatic indicators during growth, development and yield. This method is easy to apply and less expensive. In this research we decided to use the statistical method.

Crop yields consist of 2 components: trend productivity (depending on cultivation conditions: soil fertility, fertilizer, seed, crop protection measures, planting techniques and care) and weather productivity (affected by weather) (Figure 1). 


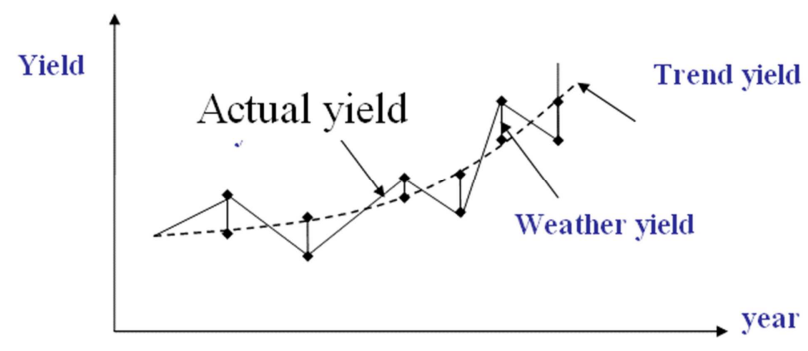

Figure 1. The relationship between the components of crop yields.

The difference between the actual yields with the trend yield is the yield caused by weather:

$$
\text { YTT }=\text { YT }- \text { YXT, }
$$

where: YTT is weather productivity $(\mathrm{kg} / \mathrm{ha})$; YTisnet yield $(\mathrm{kg} / \mathrm{ha})$; YXT istrend productivity.

Based on studying time series of weather productivity and climatic factors at the same time, the impact of climate on each crop yield is evaluated.

\subsection{Methods of assessing the reliability of the correlation coefficient}

Verification of the magnitude of the correlation coefficient is commonly used in the study of the impacts of climate variation on crop yields to provide objective conclusions about the correlation between variables $[1,3,7]$.

The equations for verifying the relationship between two series is as follow [6]:

$$
-t_{\alpha / 2, n-1} S_{r}<r_{k}<+t_{\alpha / 2, n-1} S_{r} \quad S_{r}=\frac{1}{\sqrt{n}}
$$

In particular, $r_{k}$ iscorrelation coefficient; $S_{r}$ isstandard error of the autocorrelation coefficients $\mathrm{r}_{\mathrm{k}} ; t_{\alpha / 2, n-1}$ is the percentage of distribution $\alpha$ of Student's distribution with n-1 degree of freedom. Qis usually set to be 0.15 in this circumstance [1].

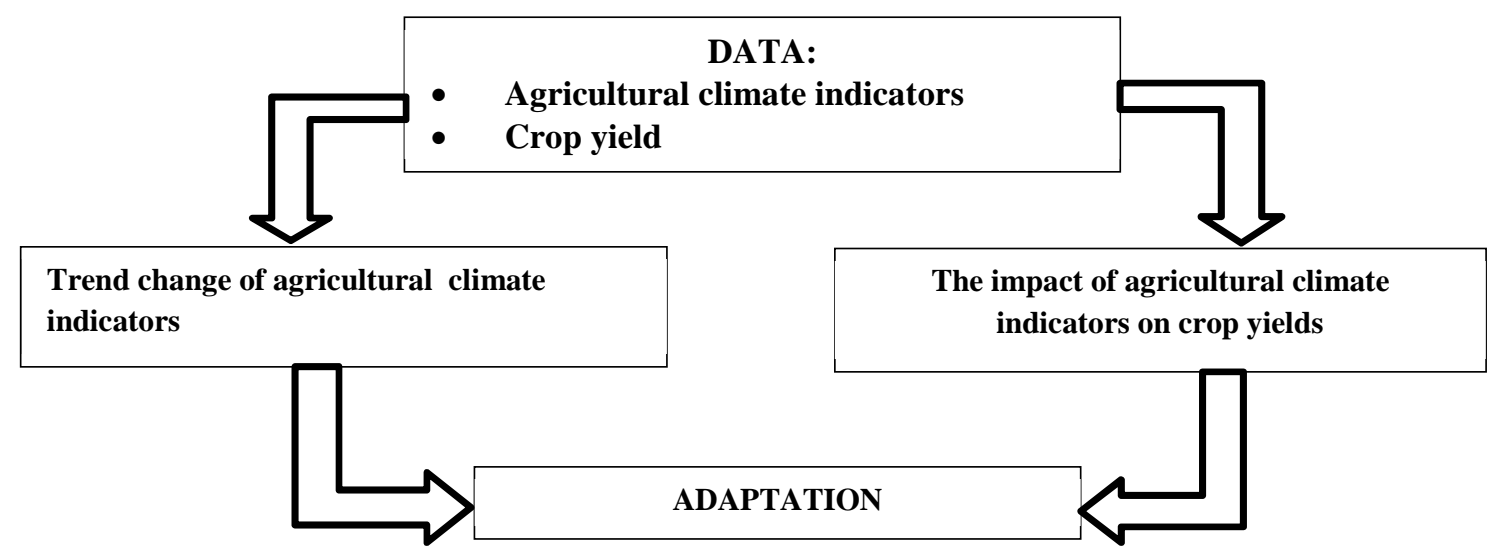

Figure 2. The conceptual framework. 
Because the number of samples is 18 (from 1996-2013), the coefficient of correlation between crop yield with climate factors beyond \pm 0.23 is considered correlations significant in terms of statistics with a significance level of 0.05 .

Framework to carry out the research is represented in Figure 2.

\section{RESULTS AND DISCUSSION}

\subsection{Trends of agro-climatic indicators in Son La}

The study of assessing changing trends of main agro-climatic indicators in Son La deducedthe following results:

The total heat in Winter-spring season (from January to June), the total heat in the season (from July to December)) and total annual heat tend to increase (Winter-Spring crop increases by 43 degrees/decade; Summer-Autumn crop increases by 33 degrees/decade. The whole year increases by 77 degrees/decade).

- The annual absolute minimum temperature tends to rapidly increase, approximately $0.6{ }^{0} \mathrm{C} /$ decade.

- The Winter-Spring rainfall is expected to slightly increase, around $10 \mathrm{~mm} /$ decade, rainfall in harvest season is supposed to decline ofabout $27 \mathrm{~mm} /$ decade, annual total rainfall is predicted to fall to about $15 \mathrm{~mm} /$ decade.

- The precipitation in Winter-Sping is projected to marginally go up, roughly $6.8 \mathrm{~mm} /$ decade; in harvest season, it is forecasted to significantly rise $(14.8 \mathrm{~mm} /$ decade $)$, the yearly trends is raised to nearly $31.2 \mathrm{~mm} /$ decade.

Table 1. The changing trends of total heat and total rainfall in the period 1961-2013.

\begin{tabular}{|l|l|l|l|}
\hline \multicolumn{1}{|c|}{ Indicators } & $\begin{array}{c}\text { Winter - Spring } \\
\text { (January to May) }\end{array}$ & $\begin{array}{c}\text { Harvest season } \\
\text { (June to October) }\end{array}$ & \multicolumn{1}{c|}{ All year } \\
\hline Total heat & Increase $43{ }^{\circ} \mathrm{C} /$ decade & Increase $33^{\circ} \mathrm{C} /$ decade & Increase $77^{\circ} \mathrm{C} /$ decade \\
\hline $\begin{array}{l}\text { Annual absolute } \\
\text { minimum } \\
\text { temperature }\end{array}$ & & & Increase $0.6{ }^{\circ} \mathrm{C} /$ decade \\
\hline Total rainfall & Increase $10 \mathrm{~mm} /$ decade & Decrease $27 \mathrm{~mm} / \mathrm{decade}$ & Decrease $15 \mathrm{~mm} /$ decade \\
\hline Total evaporation & Increase $6.8 \mathrm{~mm} /$ decade & Increase $14.8 \mathrm{~mm} /$ decade & Increase $31.2 \mathrm{~mm} /$ decade \\
\hline
\end{tabular}

The favourable period for the growth and development of temperate plants are likely to be shorter (starting day with temperature below 20 degrees tends to come later for about 2.3 days/decade, ending day with temperature below 20 degrees has tendency to arrive earlier for 2.7 days/decade. In contrast, period with temperature above 25 degrees tend to last longer (starting day with temperature above 25 degrees come earlier for about 2.9 days/decade, ending day with temperature above 25 degrees tends to come later than for approximately 8.7 days/decade). 
Table 2. The changing trends of the start day and end day which the air temperature excess $20{ }^{\circ} \mathrm{C}$ and $25{ }^{\circ} \mathrm{C}$.

\begin{tabular}{|l|c|l|ll|}
\hline \multicolumn{1}{|c|}{ Indicators } & \multicolumn{1}{c|}{ Start day } & \multicolumn{1}{c|}{ End day } & \multicolumn{2}{|c|}{ Effect } \\
\hline Excess $20^{\circ} \mathrm{C}$ & Delay 2.3 days/decade & 2.7 days/decade earlier & $\begin{array}{l}\text { Cold period will be } \\
\text { shortened }\end{array}$ \\
\hline Excess $25^{\circ} \mathrm{C}$ & 2.9 days/decade earlier & Delay 8.7 day/decade & $\begin{array}{l}\text { Hot period will be } \\
\text { expanded }\end{array}$ \\
\hline
\end{tabular}

The absolute minimum annual temperature tends to rise rapidly (about 0.6 degrees/decade).

The rainfall of the Winter-Spring crop (from January to May) tends to go up slightly (10 $\mathrm{mm} /$ decade), the rainfall of the season crop (from May to October) tend to decline (27 $\mathrm{mm} /$ decade), total annual rainfall tends to decrease $(15 \mathrm{~mm} /$ decade $)$.

\subsection{The influence of climate on main crop yields in Son La province}

\subsubsection{Components of trend yield and weather yield of the plants}

Based on surveying the suitability of the trend curve obtained from different methods (moving average method, regression, conditioning weight methods, etc.), we have identified rice yield sequence of Winter - Spring crop (Figure 3), Summer-Autumn crop (Figure 4), maize (Figure 5) and soybeans (Figure 6).

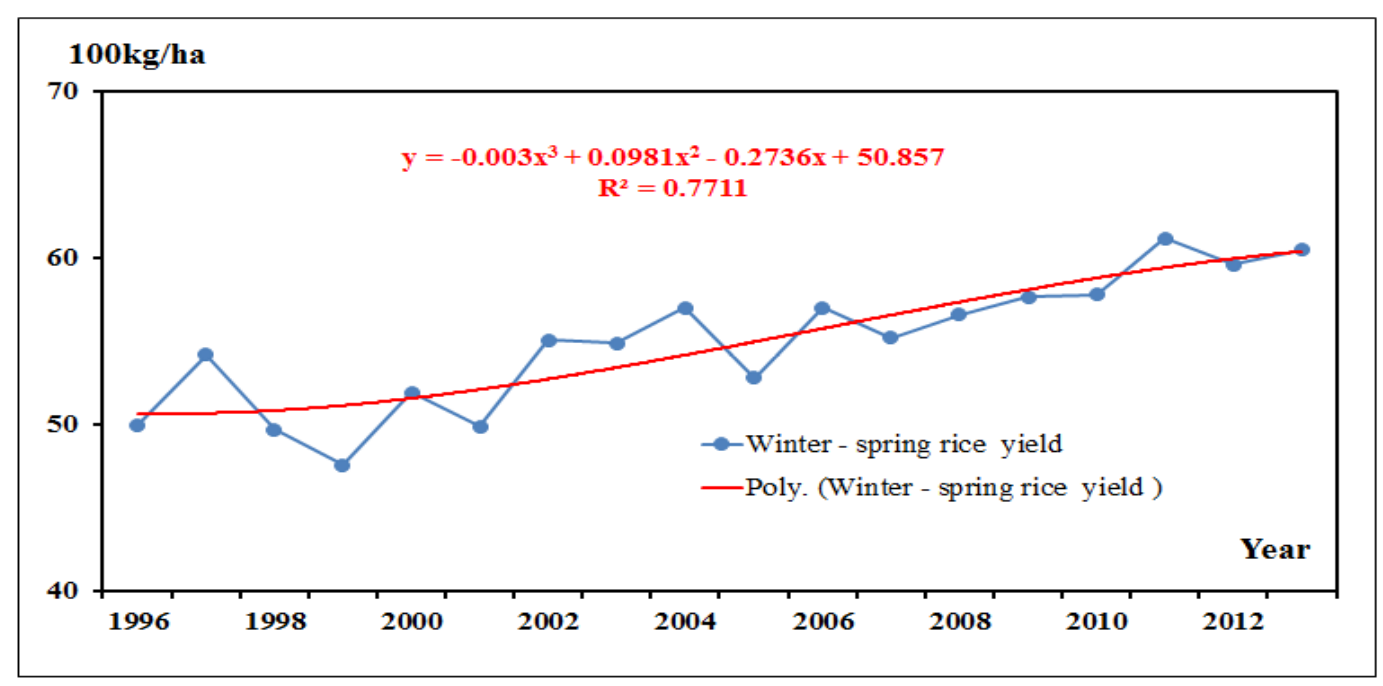

Figure 3. Actual rice yield and trend rice yield of Winter-Spring crop (Son La province). 


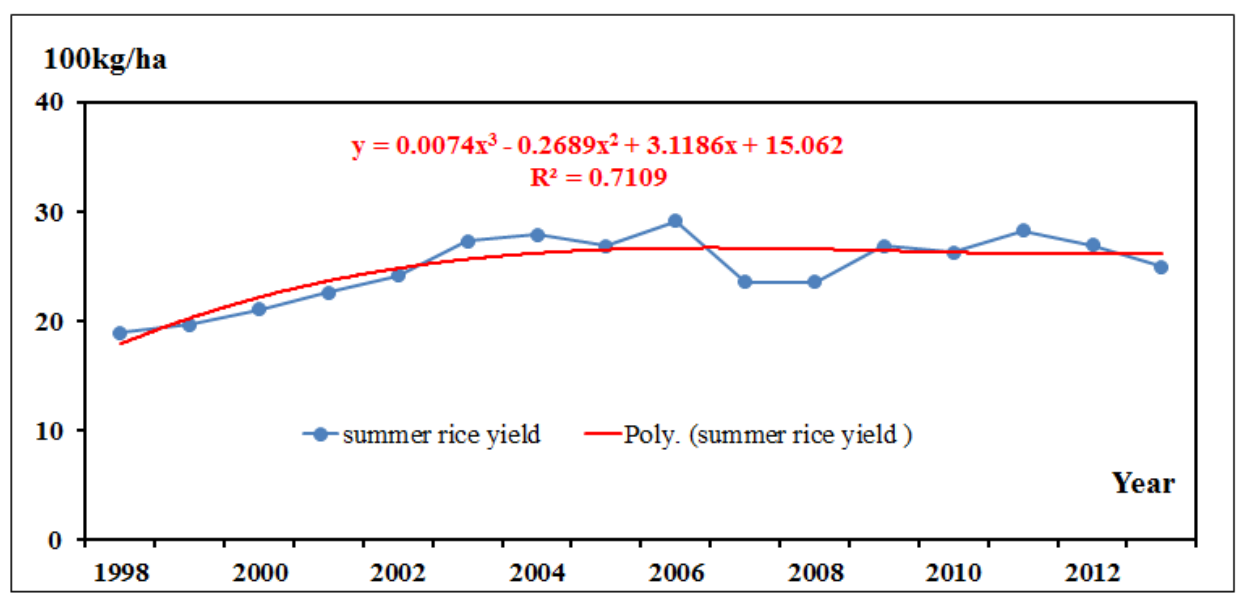

Figure 4. Actual rice yield and trend rice yield of Summer-Autumn crop (Son La province).

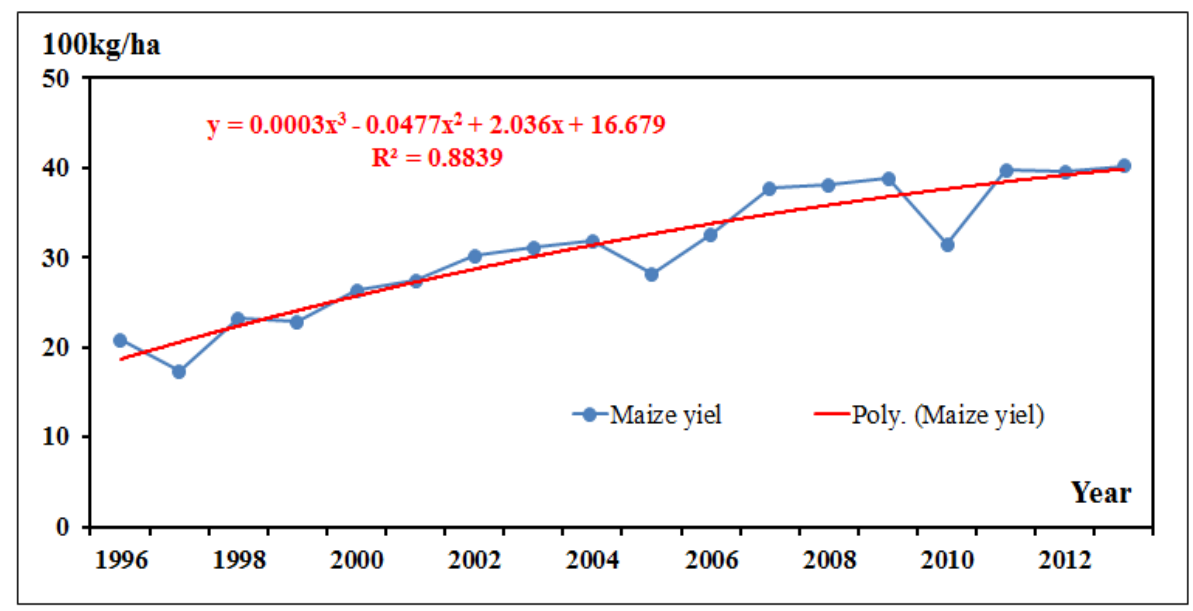

Figure 5. Actual yield and trend yield of corn (Son La province).

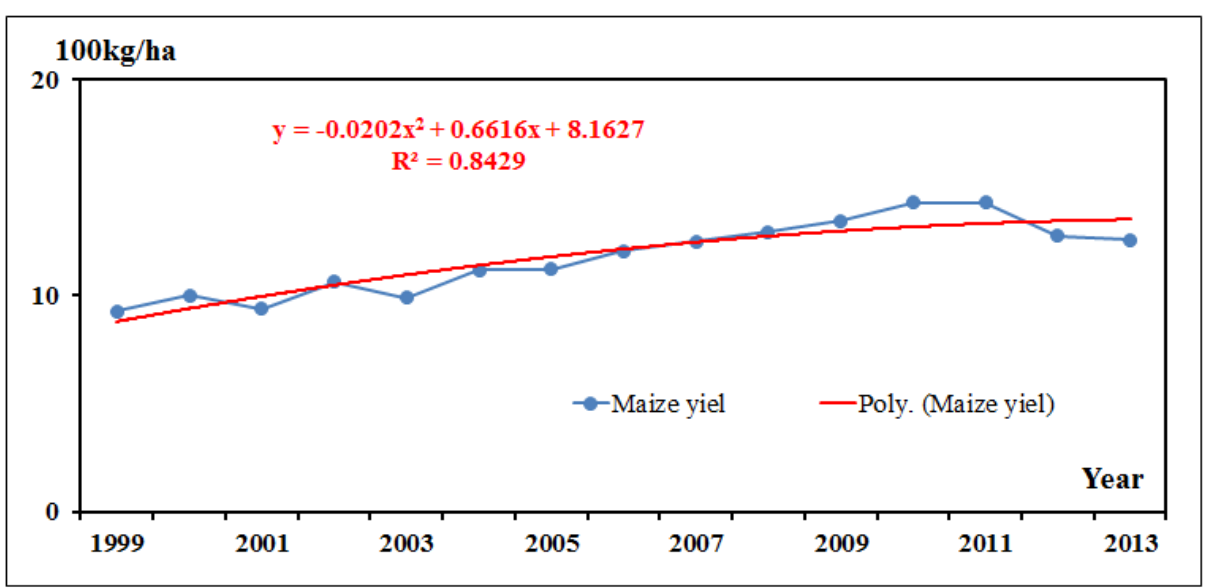

Figure 6. Actual yield and trend yield of soybeans (Son La province). 
In Son La, trend yields of three crops (rice, corn and soybeans) tend to rise. In particular, winter-spring rice and maize have faster trend yield than rice and soybean crops (Figure 3, Figure 4, Figure 5, Figure 6). Based on series/chains of actual yield and trend yield of the plants, we can determine the impact of climate factors on crop yields (Figure 7).

Weather yield of some crops in Son La province fluctuates quite greatly throughout years (Figure 6).

\subsubsection{The relationship between weather crop yields with climate factors}

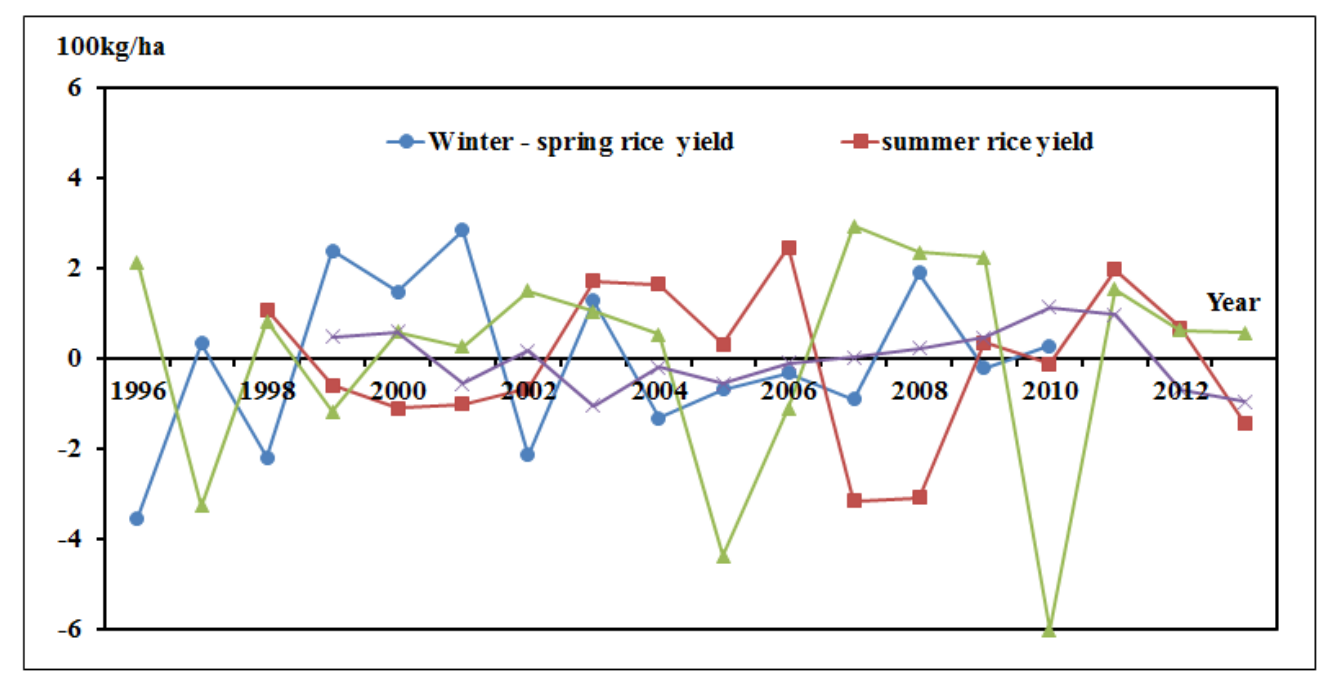

Figure 7. Weather yield of some crops mainly in Son La.

Based on the calculated correlation coefficients between weather yields of each crop type with agro-climatic factors, we can assess the impacts of climate on main crop yields of in Son La with different season frame.

\subsubsection{In terms of Winter-Spring rice crops}

Table 3 shows the correlation coefficient with statistical significance (correlation value beyond the range \pm 0.23 ).

In Son La, all the major climatic factors have a relationship with the Winter-Spring rice crop. Among them, rice is most impacted in March, April. This is the booting and flowering stage of rice, so it is very sensitive to the weather phenomenon (Table 3 ).

On the other hand, temperature and evaporation variations are inversely correlated with rice yield, which means that Winter-Spring crop gains higher yield in the years of temperatures and evaporation lower than average. 
Table 3. The relationship between weather productivity of Winter-Spring rice with climate factors.

\begin{tabular}{|c|l|c|c|c|c|}
\hline \multirow{2}{*}{ No } & \multirow{2}{*}{ Climate features } & \multicolumn{4}{|c|}{ Months } \\
\cline { 3 - 6 } & & I & II & III & IV \\
\hline 1 & Monthly average temperature & -0.32 & & -0.26 & -0.24 \\
\hline 2 & Monthly highest/maximum average temperature & -0.32 & & -0.34 & \\
3 & Monthly lowest/minimum average temperature & & & & -0.47 \\
4 & Total monthly rainfall & & & 0.29 & 0.24 \\
\hline 5 & Highest daily rainfall per month & & & 0.33 & \\
\hline 6 & Total monthly evaporation & -0.36 & -0.45 & -0.55 & -0.30 \\
\hline 7 & Relative monthly average humidity & & 0.32 & 0.33 & \\
\hline 8 & Total hours without sunlight & & & -0.39 & 0.25 \\
\hline
\end{tabular}

\subsubsection{In terms of Summer-Autumn rice crop}

In general, rice crop in Son $\mathrm{La}$ is quite sensitive to weather changes, especially the months of early and late stages. Some features of precipitation and evaporation reach a very high correlation coefficient with rice yield $( \pm 0.7)$.

If the Summer-Autumn rice usually gains high yield in years with temperatures higher than average, years with much rainfall often result in low yield (negative correlation).

Table 4. The relationship between weather productivity of season rice crop with climate factors in Son La province.

\begin{tabular}{|c|c|c|c|c|c|c|}
\hline \multirow{2}{*}{$\mathbf{N}_{\mathrm{o}}$} & \multirow{2}{*}{ Climate features } & \multicolumn{5}{|c|}{ Months } \\
\hline & & VI & VII & VIII & IX & $\mathrm{X}$ \\
\hline 1 & Monthly average temperature & 0.36 & 0.50 & & & \\
\hline 2 & $\begin{array}{l}\text { Monthly highest/maximum average } \\
\text { temperature }\end{array}$ & 0.25 & & & & 0.54 \\
\hline 3 & $\begin{array}{l}\text { Monthly lowest/minimum average } \\
\text { temperature }\end{array}$ & 0.35 & & & & \\
\hline 4 & Total monthly rainfall & -0.45 & -0.59 & & -0.56 & -0.66 \\
\hline 5 & Highest daily rainfall per month & -0.44 & -0.25 & & -0.60 & -0.75 \\
\hline 6 & Total monthly evaporation & & 0.61 & 0.36 & 0.42 & 0.76 \\
\hline 7 & Relative monthly average humidity & & & 0.27 & & -0.67 \\
\hline 8 & Total monthly sunshine hours & & 0.34 & & & 0.37 \\
\hline
\end{tabular}

\subsubsection{In terms of corn}

Overall, in Son La, the climate features are related to maize yield. In particular, temperature and evaporation features have closer ties than other features (Table 5). 
Table 5. The relationship between weather productivity of corn with climate factors in Son La province.

\begin{tabular}{|c|l|c|c|c|c|c|c|c|c|c|c|c|}
\hline \multirow{2}{*}{ No. } & \multicolumn{1}{|c|}{ Climate features } & \multicolumn{10}{|c|}{ Months } \\
\cline { 3 - 13 } & & I & II & III & I & V & VI & VII & VIII & IX & X & XI \\
\hline 1 & Monthly average temperature & -0.47 & & & & -0.55 & -0.45 & -0.41 & 0.37 & & & -0.31 \\
2 & $\begin{array}{l}\text { Maximum monthly average } \\
\text { temperature }\end{array}$ & & & & -0.57 & -0.53 & & 0.54 & & & -0.34 \\
\hline 3 & $\begin{array}{l}\text { Minimum monthly average } \\
\text { temperature }\end{array}$ & -0.54 & & 0.26 & -0.28 & -0.24 & -0.63 & & & & \\
4 & $\begin{array}{l}\text { Total monthly rainfall } \\
5\end{array}$ & -0.26 & & -0.36 & 0.45 & & 0.33 & & & & 0.31 \\
\hline 6 & Highest daily rainfall & -0.26 & & -0.31 & & & 0.28 & & 0.27 & & \\
\hline 7 & $\begin{array}{l}\text { Total monthly evaporation } \\
\text { humidity average relative }\end{array}$ & & -0.36 & & -0.54 & -0.46 & -0.43 & 0.56 & & & \\
\hline 8 & Total monthly sunshine hours & & & & & & & & -0.60 & -0.24 & & 0.26 \\
\hline
\end{tabular}

\subsubsection{In terms of soybean}

Table 6. The relationship between weather productivity of soybean with climate factors in Son La province.

\begin{tabular}{|c|c|c|c|c|c|c|c|c|c|c|c|c|}
\hline \multirow{2}{*}{ No. } & \multirow{2}{*}{ Climate features } & \multicolumn{11}{|c|}{ Months } \\
\hline & & I & II & III & IV & V & VI & VII & VIII & IX & $\mathrm{X}$ & XI \\
\hline 1 & $\begin{array}{l}\text { Monthly average } \\
\text { temperature }\end{array}$ & & & & & & & 0.35 & & 0.38 & -0.29 & -0.44 \\
\hline 2 & $\begin{array}{l}\text { Maximum } \\
\text { monthly average } \\
\text { temperature }\end{array}$ & & & & -0.37 & -0.24 & & 0.35 & & 0.38 & -0.29 & -0.28 \\
\hline 3 & $\begin{array}{l}\text { Minimum monthly } \\
\text { average } \\
\text { temperature }\end{array}$ & & -0.30 & & & -0.26 & & & & 0.34 & & -0.45 \\
\hline 4 & $\begin{array}{l}\text { Total monthly } \\
\text { rainfall }\end{array}$ & & & & & & & -0.52 & -0.26 & & & \\
\hline 5 & $\begin{array}{l}\text { Highest daily } \\
\text { rainfall }\end{array}$ & & & 0.42 & & & & -0.38 & & & & \\
\hline 6 & $\begin{array}{l}\text { Total monthly } \\
\text { evaporation }\end{array}$ & & & & -0.44 & & -0.47 & & & & -0.37 & -0.28 \\
\hline 7 & $\begin{array}{l}\text { Monthly average } \\
\text { relative humidity }\end{array}$ & -0.32 & -0.25 & & 0.31 & & & & & & 0.30 & \\
\hline 8 & $\begin{array}{l}\text { Total monthly } \\
\text { sunshine hours }\end{array}$ & & & & -0.36 & & & & & & & \\
\hline
\end{tabular}

Compared to maize and rice, the level of the relationship between climate variables with soybean yield is often less stringent. This shows that the soybean has broader ecological limits to climatic factors. Thus, soybean yield is often more stable than other crops.

\subsection{The climate features of the years with high/low yield}


Indicator in high/low yield on each plant is determined according to the level of weather yield series (year of high yield is the year with weather yield greater than 70th percentile, year of low yield is the year with weather yield smaller than $30^{\text {th }}$ percentile.

For Winter-Spring rice: The climate characteristics between high yield crops and low yield crops greatly differ. (High yield crop: The average temperature is 19.9 degrees; the evaporation is $438.8 \mathrm{~mm}$. Low yield crop: the average temperature is 20.8 degrees, and the evaporation is $554.9 \mathrm{~mm}$ ) (Table 7).

For rice crop: The high yield crop and the low one have a big difference in terms of rainfall and amount of sunlight (High yield year: the average rainfall is $712.0 \mathrm{~mm}$, the amount of sunlight is 831.5 hours, Low yield year: the rainfall is $1033.3 \mathrm{~mm}$, the average amount of sunlight is 792.9 hours only) (Table 7).

Table 7. Climate features in the years of high and low yield in Son La province.

\begin{tabular}{|c|l|c|c|c|c|}
\cline { 3 - 6 } No. & \multicolumn{2}{|c|}{ Climate feature } & \multicolumn{2}{|c|}{$\begin{array}{c}\text { Winter spring rice } \\
\text { crop }\end{array}$} & \multicolumn{2}{|c|}{$\begin{array}{c}\text { Summer-Autumn rice } \\
\text { crop }\end{array}$} \\
\cline { 3 - 6 } & & $\begin{array}{c}\text { High yield } \\
\text { year }\end{array}$ & $\begin{array}{c}\text { Low yield } \\
\text { year }\end{array}$ & $\begin{array}{c}\text { High } \\
\text { yield year }\end{array}$ & $\begin{array}{c}\text { Low yield } \\
\text { year }\end{array}$ \\
\hline 1 & The average air temperature per crop $\left({ }^{0} \mathrm{C}\right)$ & 19.9 & 20.8 & 24.4 & 24.2 \\
\hline 2 & The total rainfall per crop $(\mathrm{mm})$ & 427.6 & 409.9 & 712.0 & 1033.3 \\
\hline 3 & Relative average humidity per crop $(\%)$ & 78 & 75 & 83 & 84 \\
\cline { 2 - 6 } & $\begin{array}{l}\text { The total hours without sunlight per crop } \\
\text { (hour) }\end{array}$ & 782.2 & 849.2 & 831.5 & 792.9 \\
\hline 5 & The total evaporation per crop $(\mathrm{mm})$ & 438.8 & 554.9 & 360.4 & 305.9 \\
\hline
\end{tabular}

For corn and soybean: There is no significant difference in temperature, air humidity and sunny hours during the high yield years and low yield years. However, the features of rainfall and evaporation seem to differ (Table 8).

Table 8.Climate features in corn and soybean harvest and crop failure in Son La.

\begin{tabular}{|c|l|c|c|c|c|}
\multirow{2}{*}{ No. } & \multicolumn{2}{|c|}{ Climate feature } & \multicolumn{2}{|c|}{ Corn } & \multicolumn{2}{c|}{ Soybean } \\
\cline { 3 - 6 } & \multicolumn{1}{|c|}{$\begin{array}{c}\text { High yield } \\
\text { year }\end{array}$} & $\begin{array}{c}\text { Low yield } \\
\text { year }\end{array}$ & $\begin{array}{c}\text { High yield } \\
\text { year }\end{array}$ & $\begin{array}{c}\text { Low yield } \\
\text { year }\end{array}$ \\
\hline 1 & The average air temperature per crop $\left({ }^{0} \mathrm{C}\right)$ & 22.0 & 22.5 & 22.3 & 22.5 \\
\hline 2 & The total rainfall per crop $(\mathrm{mm})$ & 693.9 & 638.6 & 590.3 & 647.5 \\
\hline 3 & Relative average humidity per crop $(\%)$ & 81 & 80 & 80 & 80 \\
\hline 4 & The total sunny hours (hour) & 1620.5 & 1632.5 & 1646.3 & 1653.3 \\
\cline { 2 - 6 } 5 & The total evaporation per crop $(\mathrm{mm})$ & 773.5 & 879.9 & 792.0 & 834.2 \\
\hline
\end{tabular}




\section{CONCLUSION}

Due to the impact of climate change, the climate indicators in Son La province change according to the following trends: (i) the total annual heat increases; (ii) the period of winter tends to shorten; (iii) the absolute lowest annual temperature tends to rise; (iv) the amount of evaporation tends to increase. Therefore, production period of some crops needs to be adjusted and the risk of water shortages in some areas needs to be taken notice of.

Generally, changes of the climate factors have a relationship with crop yield. Yet, the factors with strongest influence is the temperature and evaporation (for the winter-spring rice), the temperature of rainfall (for the season rice), temperature and evaporation (for maize). Compared to other crops, soybean yields seem to have less fluctuation.

The difference between climate indicators in years with high and low yields in Son La province depends on the type of crop and season. In particular, the indicators with great difference is the average crop temperature and evaporation (for the winter-spring rice); the rainfall and sunny hours (for rice) as well as the rainfall and evaporation (For corn and soybeans).

\section{REFERENCES}

1. Institute of Meteorology, Hydrology and Environment - Handbook: Assessing the impact of climate change and identifying adaptation measures, Natural Resources - Environment and Vietnam Map Publishing House, 2011, pp. 57(in Vietnamese).

2. Oldeman L. R. and Frere M. A. - Study of the agroclimatology of the humid tropics of Southeast Asia, Technical report. FAO, Rome, 1982.

3. Yinhong Kang, Shahbaz Khan, Xiaoyi Ma - Climate change impacts on crop yield, crop water productivity and food security - A review, 2009. dx.doi.org/10.1016.

4. Prime Minister's Decision No. 1959/ QĐ-TTg dated 10/29/2013 approving the Master plan on economic - social development in Son La province by 2020 (in Vietnamese).

5. Son La Provincial Bureau of Statistics - Yearbook, Son La, 2009 (in Vietnamese).

6. Phan Van Tan - Statistical Methods in Civil Engineering, Ha Noi, 1999, pp. 27 (in Vietnamese).

7. Lobell D. B.., Field C. B., Cahill K. N., Bonfils C. - Impacts of future climate change on California perennial crop yields: Model projections with climate and crop uncertainties, Agricultural and Forest Meteorology 141 (2006) 208-218. 